\title{
"The Prisons We Broke" Associated to Self-Reliance that Eloquent itself in the Conditions of Modernity
}

\author{
${ }^{1}$ P. Revathi, ${ }^{2}$ M. R. Bindu \\ Vel Tech Rangarajan Dr. Sagunthala R\& D Institute of Science and Technology Avadi, Chennai - 62.
}

\begin{abstract}
Writing autobiographies were present in Western culture some centuries ago, but in India it stepped in recent centuries. In the Indian context, celebrating oneself was not for the ordinary people it was only meant for the Kings or noble leaders. Life writing is virtuously established by the custom of repudiation. The self here by the marginalized writer is written only to seek the humble moral qualities but not to flourish its achievements. In India, self is defined by its ethical capacity to desist from demanding recognition for attainments. Autobiography is linked to self-reliance that enunciates itself in the circumstances of novelty. Therefore, in India Writing autobiography is a modern occurrence.
\end{abstract}

Keywords:

Life writing, Self-Reliance, Repudiation, Modernity.

\section{INTRODUCTION}

Writing autobiography was found to be a new genre for Indians. It was only the upper caste men wrote autobiography unquestionably to cherish their achievements and their society. Gradually women of upper caste wrote their self indirectly in the form of Bhakti they practiced or religious song. Thinks slowly stated changing after postindependence. The marginalized writers came forward to record their life history and their community status in the society. The state Maharashtra witnessed more women writers writing autobiographies than men. It is here, the Dalit's women self-writing seems to be different from the life narratives of the upper caste. Dalit women started writing autobiographies undoubtedly only a mere twenty years back. What the Dalit women wanted was to repossess their community history by giving out voice to the subjected people. In the initial period, many critics felt that it is not possible to break the conventional narrative of the mainstream writers. Obviously, as it was felt the writings of Dalit women encountered tremendous repercussions.

The Prison We Broke in original called as Jina Amucha was the first Marathi Dalit self-writing by Baby Kamble. This text is a remonstration against
Hindu caste that has oppressed the lower caste for centuries by the upper caste. The societal meliorist like Shahu Maharaj, Mahatma Phule raised their opinions against the atrocities towards the Dalit. Dr. Bhimrao Ramji Ambedkar known as Babasaheb Ambedkar staunched his entire life in annihilating social inequality in the Hindu caste system. His leadership, challenged the very substructure of Varnashramdharma, the Brahmanical doctrine that has indorsed and disseminated the domination of Dalits.

The Dalits where controlled, disbanded by the ascendancy structures in social and dogmatic spheres. They were used largely as a destitute labours by the upper caste people of their village. The Indian National Congress came up with a policy called Green Revolution to build a bridge between the rich and the middle-class famers. Though, the intention was good the dejected class were not benefited completely. Most of them remained as a landless labours. They became the prey for ill treatment. In the so called, developed policies the dejected communities were further isolated, underprivileged even the basic needs like water, food and shelter. 


\section{ANALYSIS}

The Prisons We Broke is a direct self-declaration conflict with Brahmanical Hinduism and Patriarchal domination. This text is aptly called as socio-biography rather than autobiography. It intensely engrosses with the past of Mahar community's subjugation. For many writers in Marathi and for Baby Kamble Dr. B. R. Ambedkar was the inspirer. Kamble proclaims her writing is for her people. She explicitly states how her people had turned to be slaves and mis treated worse than animals. Her writing replicates her love for her people. The ultimate in her writing is, inspite of; outraging the inhuman conditions and sufferings of her people, nowhere, one could find despond in her attitude of narration. Instead, we can find a sense of humour when she describes certain incidents during rituals. The woman takes a chance to make the men to fall in her feet when she possesses Goddess. She utters some fearful words:

The men of the house would then literally fall at his wife's feet. He begged her to have mercy on him, 'Oh holy mother, I fall at your feet and beg you, don't be angry with me - I accept all my mistakes (2008, P.27)

She also describes how the children eat in a funny way. Once the goddess departs from the body of the woman after giving some good omen, she asks the girls and children who is watching the ritual dramas to eat.

Come on girls, now for the food! Say the mother's name and start eating! The children would have polished off half the plate by this time......... The children would again attack it.... the sweet food pacified their ever hungry, burning stomachs at least once during the whole year (2008, P.28)

One another momentous feature Kamble conveys out is the internal shock in the psyche of her people on the verge of a central alteration. Another important aspect of her text is Dalit feminist analysis of patriarchy. Kamble brashly depicts the emotional and corporeal attack, a woman undergoes in public and private sector from the upper caste people as well by their own men. She points out that the Mahar community is seen as the other in the eyes of upper class, but within the community the Mahar woman is seen as the "other" by Mahar men. She brings out discursive practices which have been seldom conversed in mainstream writing.

As a woman Kamble suffered like any other woman in the name of patriarchy. She was beaten by her husband for no reasons. She had to face this kind of violence throughout her life time. She highlights an incident that happened to her when she travelled to Mumbai. she was beaten by her husband in train for a man rubbernecked at her in general compartment. It was not her mistake, inspite of it she had to accept this kind of physical assault from her husband. This was an attitude of everyman towards their women. By bringing out this she is trying to depict the life of her community women led constantly. She gained her strength in accepting her husband as he is and continuously reinforced by her communal men and women.

\subsection{Restructuring}

Initially, the Mahars faced a countless scuffle. A continuous conflict with the upper caste prevailed in all the fields. They were not allowed to enter the village and therefore, for the Dalits everything was out of frontier. The so-called upper caste, wanted to sojourn the upliftment of these Dalits. They tried to make their life threatening. They were not given any work as a result they were pushed down economically but Kamble's father 
was able to accomplish things by some means. Women started partaking much later when they became educated. Meanwhile, Kamble started to give speech in public and more women began to contribute to the revolt by having inspired by women like Kamble. Raja Malojiraje Nimbalkar had taken initiative to make a Mahar woman as a member of the Mahila Mandal. Many women form Kamble's place became a member and did not vacillate to fight for their human rights. As a sample of restructuring, they went to a height of demanding a chair to sit and participated in the debates.

\subsection{Maharwada women}

Most of the women from Mumbai actively took part in the public meetings that was conducted at Chawdi. They trusted Dr.B.R. Ambedkar for his wisdom and astonishing speech. They powerfully whispered that only women can bring light into their lives. They revered Babasaheb and he became the midpoint of conversation amongst them. They found him saying something different which no one heard before. They sturdily believed Babasaheb and his ideology will help them in uplifting their society. The women instigated to join assemblies even at distant or remote places. They took part in protest like forcibly entering into the temples, hotels and other common places where these Dalits were kept away. Surprisingly, they were supported by their men folks. This was a major transformation among the group. When all these reformations ensued Kamble was only twelve-years-old. Because of her brother, she always got a chance to contribute in all the programmes.

\subsection{Education}

The agonize of her community was seen as her own suffering. Kamble found it be tough to contemplate out side her community. She was able to relate other women with herself. These women were determined in educating their children as a result, they enrolled their children in schools. They strongly believed the words of
Ambedkar. She highlighted the speech given by Ambedkar at Chawdi:

From now onwards you have to follow a different path. You must educate your children. Divorce your children from god. Teach them good things. Send them to school, the result will be there for you to see. When your children begin to be educated, your condition will start improving. Your family, your life will improve. Your children will bring you out of this hell. We are humans. We, too, have the right to live as human beings. Your children will make you aware of this (2008, P.64)

Getting education for their sons and daughters was not a piece of cake. They had no money to educate them. With a kind of cleverness and commitment they were able to make their children study and they did whatever Babasaheb asked for. When it came to God or education? Babasaheb motivated them to select education. Women of Maharwada played a big role in educating their kids.

\subsection{Proclamation}

Kamble was stunned when she read a story from a book which portrayed stories about gods and their great deeds. She was worried when she read the story of Vrinda, a Shudra princess were all erroneous. Vridha married Jalandar, son of Shudra king. She was a virtuous woman which made her husband very robust. He was not able to defeat by gods. The Gods realized it was Virnda's virtue protected Jalander being defeated. God Vishnu came in the disguise of Jalander and took her to bed. The instant she lost her virtue, her husband was slayed in the battle. Only then Virnda comprehended how dreadfully she was deceived by god. Later, she was given a boon by Vishnu, that she will be always Sowbhagyawathi. People 
perform Tulasi vivaha every year at the outside of their house by tying a knot to the Tulasi plant. Since Virndha, is a Shudra she was kept outside the house. When Kamble read this story, she was literally anger for portraying the lower the caste god. The story depicted how the upper caste had mythologized the subjugation of Shudra men and women. This instant made her think that she must proclaim to the universe what she and her community suffered.

\subsection{Hidden writing}

Kamble happened to write when she was in her shop. She had plenty of time to write. She was left alone at shop from morning nine to four where her husband would leave the shop for buying goods. She began to write all her sufferings into words. For her, writing was a difficult task because she had to hide her writing from her family members. She kept her writing secretly because she was scared of her husband. Her husband considered women to be an inferior human being. Meantime, her son started to go to school. Now she was afraid of her son as well as her husband reaction if they come to know about her life writing. She kept her papers concealed for twenty years. It was Maxine Bernston, a sociologist helped her to publish her work. Her family came to know that she was a writer only when her book was published. Many young people greeted her writing as she depicted the life of women how it had not altered for hundred of years.

\subsection{Post-Ambedkar Dalit Movement}

Once after the death of Dr. Ambedkar in 1956 everything went upside down. There was no one to guide them. People got disordered what to do and whom to track as a front-runner. Everybody wanted to act as Dr. Ambedkar. Many came forward gusting their trumpet. Kamble quotes an example how post-Ambedkar Dalit movement was. People believed Ramdas Athawale would be right choice to lead the community as he was brilliant and passionate in participating the riots from Dalit Panther. They believed him more than the Republican Party. People fetched confidence that everything will be set in the place as Ambedkar expected. The upper-class people who couldn't tolerate this bought Ramdas by giving him a promise that they will make him as a minister. Therefore, Dalit Panthers became weak. That was the end and there were no one to think about the suppressed people and provide any kind of assistance for their upliftment.

\section{CONCLUSION}

The self-writing The Prisons We Broke brings out the nastiest form of mistreatment of their community in one sense and physical and psychological torment that Dalit male perpetrated on Dalit women in another sense. Her life writing helps or bids numerous significant hints and evidences to research on the epistemic issues of poise and self-esteem and much discussed problems like custom and modernity.

\section{References}

[1] Kamble, Baby. 2008. 'Jina Amuche' translated by Maya Pandit as The Prisons We Broke. New Delhi: Orient Blackswan.

[2] Bhattacharya, Nilanjana. Rev. of The Prisons We Broke by Baby Kamble. JJCL 46 (2008-2009). Academia.edu. Web. 14 Nov. 2011

[3] Limbale, Sharankumar. Towards an Aesthetic of Dalit Literature: History, Controversies and Considerations.New Dellhi: Orient BlackSwan, 2014.

[4] Srinivas, M. N. Caste in Modern India and other Essays.1962. Bombay. Asia Pub. House Print. 